\title{
EFFECT OF FINANCIAL PERFORMANCE, AUDIT QUALITY, INDEPENDENT COMMISSIONER ON EFFECTIVE TAX RATE
}

\author{
Titis Widya Yanti, Kartika Hendra, Yuli Chomsatu \\ Universitas Islam Batik, Kota Surakarta, Indonesia \\ titiswidyayanti2716@gmail.com
}

\begin{abstract}
This study aims to analyze the influence of financial performance, quality audit, independent commissioner to the effective tax rate. By using a sample of 30 real estate \& property company listed in Indonesia Stock Exchange in the year 2015 to 2018 the number of data 71 after deducting the data outlayer. The method used is multiple linear regression. The results of this analysis, the variable size of the company does not affect the effective tax rate, leverage does not affect the effective tax rate, profitability affect the effective tax rate, capital intensity ratio does not affect the effective tax rate, inventory capital ratio affect the effective tax rate, quality audit affect the effective tax rate, independent commissioner affect the effective tax rate. Based on the test of the coefficient of determination ( $R 2)$ equal to $27.3 \%$ of the variable effective tax rate can be explained by the variable firm size, leverage, profitability, capital intensity ratio, inventory capital ratio, quality audits, independent commissioner while $72.7 \%$ are influenced by variables other.
\end{abstract}

Keywords: financial performance; KAP; Independent Commissioner; ETR

\section{INTRODUCTION}

Indonesia is a developing country that has a high potential of taxation. With the tremendous growth in the number of companies in Indonesia which is one of the real estate sector and property to make the government hopes the tax in Indonesia is also increasing as well. Given the importance of the role of taxes for the government. The government has tried to be no escape from paying taxes. However, it betolak back to the company trying to manage taxes in order to reduce the tax burden paid for not too much parse profits.

The company's growth in Indonesia to make the government in
2008 did make up about taxation in a revised Law No.36 with a decreased incentive tax rates for corporate taxpayers. But there are still a lot of tax evasion practices in Indonesia. For example, in 2019 the DGT studying case Adiro Energy Tbk PT suspected cult of transfer pricing with a subsidiary in Singapore to sell coal at a bargain price to a subsidiary and then resold at a higher price. Through the company Global Witness discovered the potential tax payments lower than it should be worth \$ 125 million US to the Indonesian government. (Kompas.com).

There gap research in this study the variables of variable size 
EAJ (Economics and Accounting Journal) - Vol. 3, No. 1, Jan 2020 - Yanti, Hendra \& Chomsatu

companies with effective tax rate is the research conducted by Batmomolin (2018) which states the size of the company affect the ETR while research Rahmawati and Mildawati (2019) states that the size of the company does not affect the ETR. Variable leverage with the ETR is the research conducted by the Earth et al (2018) demonstrate that the leverage effect on the ETR. Batmomolin (2018) stated leverage does not affect the ETR. Variable profitability with effective tax rate is the research conducted by the Women and Gunawan (2017) stated that profitability affects the ETR. While the research conducted by Ambarukmi and Diana (2017) states otherwise. variablescapital intensity ratio the effective tax rate is the research conducted by Ambarukmi and Diana (2017) proved that capital intensity ratio affects the ETR while research conducted by Batmomolin (2018) states capital intensity ratio does not affect the effective tax. Inventory variable capital ratio with effective tax rate is the research conducted byPertiwi et al (2018) states that inventory capital ratio

\section{LITERATURE REVIEW}

\subsection{Agency Theory}

Agency theory explains that pemisahaaan between management functions (management) with the function of ownership in a company (shareholders).

\subsection{Effective Tax Rate}

Effective tax rate which is the ratio between the real tax we pay affect the effective tax rate, while research conducted by Batmomolin (2018) suggest otherwise. The variable quality of the audit with the effective tax rate is the research done Salaudeen and Akano (2018) stated that the quality of audits affect the effective tax rate, while research conducted byWang et al (2014) state that does not affect the quality audit effective tax rate, variable independent commissioner witheffective tax rate research conducted by Wulansari et al (2015) states that an independent commissioner affect the effective tax rate, while research conducted by susiliwati et al (2018) showed no effect on the independent commissioner effective tax rate,

Much research has been done on factors that may affect the effective tax rate, but the results are found to be varied accordingly authors conducted a study using variables has the writer explained above. So in this research, we examined the backthe effect of financial performance, quality audit, an independent commissioner to effective tax rate.

with commercial profit before tax (Richardson and Lanis, 2007).

\section{3. size of company}

The size of the company is a benchmark used to determine the size of the company's operations. The bigger the company led to the company becoming victims of greater regulation by the government.

\section{4. leverage}

* Corresponding author's e-mail: titiswidyayanti2716@gmail.com 
EAJ (Economics and Accounting Journal) - Vol. 3, No. 1, Jan 2020 - Yanti, Hendra \& Chomsatu

leveregeis a ratio used to measure a company's ability to pay all its obligations, both short- and long-term if the company is dissolved (Kashmir, 2017).

\subsection{Profitability}

Profitability is the ratio used to assess the ability of a company to seek profit or profit in a particular period. Profitability can be measured by OA.

\subsection{Intensity Capital Ratio}

Capital Intensity Ratiois the investment activities undertaken by the company related to investments in fixed assets (fixed asset intensity).

\subsection{Intensity capital ratio}

The ratio between the amount of inventory to total assets of the company. Costs incurred because of their large inventory could reduce corporate profits.

\subsection{Quality audits}

Audit quality is the performance of auditors in the audit process in accordance with professional standards of public accounting (SPAP), audit expertise, and code of conduct of public accounting profession.

\subsection{Independent commissioner}

Independent commissioners are outsiders who do not have the internal relationships in companies either directly or indirectly. The management board of commissioners will be difficult to make cheating on taxes to be paid.

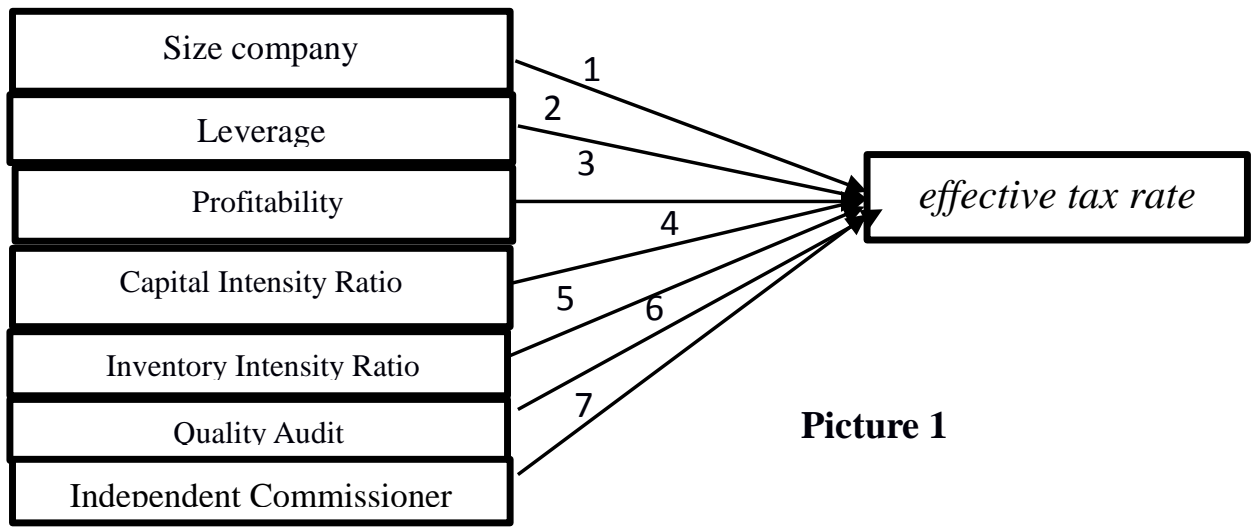

\subsection{Formulation Of Hypotheses}
$\mathrm{H} 1$ = Size companies affect the effective tax rate
H6 = Quality audits affect the effective tax rate
$\mathrm{H} 7$ = independent Commissioner affect the effective tax rate

$\mathrm{H} 2$ = Leverage affect the effective tax rate

H3 = Profitability affect the effective tax rate

$\mathrm{H} 4=$ Capital intensity ratio affect the effective tax rate

$\mathrm{H} 5$ = Inventory capital ratio affect the effective tax rate

\section{RESEARCH METHODS}

This research is classified by associative causal research that aims 
EAJ (Economics and Accounting Journal) - Vol. 3, No. 1, Jan 2020 - Yanti, Hendra \& Chomsatu

to determine the causal relationship between two or more independent variables and the dependent variable (Gurawati, 2013).

\subsection{Data collection technique}

This study uses secondary data in the form of annual report taken from the Indonesia Stock Exchange www.idx.com and on the official website of real estate companies and property.

\subsection{Operational definition of variables}

Depended variable used is the effective tax rate while the dependent variable in this study are Size company, Leverage, Profitability, Capital intensity ratio, capital ratio

\section{RESULTS AND DISCUSSION}

\subsection{Descriptive Statistics}

Descriptive statistical analysis is used to illustrate the mean value,
Inventory, Quality audits, independent.

\subsection{Sample collection techniques}

The population in this study real estate and property company listed on the Stock Exchange in 2015-2018. To determine the sample using purposive sampling. The sample in this study 30 real estate companies and properties listed on the Stock Exchange in the year 2015 to 2018 with the amount of data the data outlayer 49120 minus the data so the processed data are 71 Data

\subsection{Data analysis technique}

Data analysis technique used is multiple linear regression

\section{Table 1: Descriptive statistics}

\begin{tabular}{|lccccc|}
\hline \multicolumn{1}{r}{ variable } & $\mathrm{N}$ & noodles & $\max$ & mean & $\begin{array}{c}\text { Std. } \\
\text { devia }\end{array}$ \\
\hline DER & 71 & 27.84 & 31.58 & 29.75 & 0.98 \\
ROA & 71 & 0.06 & 3.70 & 0.76 & 0.61 \\
CIR & 71 & 0.01 & 0.26 & 0.07 & 0.05 \\
ICR & 71 & 0,00 & 0.70 & 0.09 & 0.14 \\
KA & 71 & 0,00 & 0.73 & 0.24 & 0.20 \\
KI & 71 & 0,00 & 1.00 & 0.26 & 0.44 \\
ETR & 71 & 0.25 & 0.67 & 0.39 & 0.08 \\
\hline
\end{tabular}

Source: Descriptive statistics

\subsection{Classic Assumption Test}


EAJ (Economics and Accounting Journal) - Vol. 3, No. 1, Jan 2020 - Yanti, Hendra \&

Chomsatu

\section{Normality Test}

Table 2: One Sample KS-Test

\begin{tabular}{llll}
\hline & Sig & Std & Information \\
\hline Asymp.Sig. & 0.06 & $>$ & Normal \\
(2-tailed) & & 0.05 & \\
\hline
\end{tabular}

Source: results of data processing SPSS 22

\section{Test Multicolinearity}

Table 3: Test Results Multicolinearity

\begin{tabular}{|l|l|l|l|l|l|}
\hline & $\begin{array}{l}\text { Toler } \\
\text { an }\end{array}$ & Std & VIF & Std & Information \\
\hline SIZE & 0.634 & $>0.1$ & 1,577 & $<10$ & $\begin{array}{l}\text { No } \\
\text { Multicolinearity }\end{array}$ \\
\hline DER & 0.719 & $>0.1$ & 1.392 & $<10$ & $\begin{array}{l}\text { No } \\
\text { Multicolinearity }\end{array}$ \\
\hline ROA & 784 & $>0.1$ & 1.275 & $<10$ & $\begin{array}{l}\text { No } \\
\text { Multicolinearity }\end{array}$ \\
\hline
\end{tabular}

From the table above it can be seen that the value of all the variables have more tolerance value

\begin{tabular}{|l|l|l|l|l|l|}
\hline CIR & 0.657 & $>0.1$ & 1,522 & $<10$ & $\begin{array}{l}\text { No } \\
\text { Multicolinearity }\end{array}$ \\
\hline CR & 0.693 & $>0.1$ & 1,443 & $<10$ & $\begin{array}{l}\text { No } \\
\text { Multicolinearity }\end{array}$ \\
\hline KA & 0.678 & $>0.1$ & 1.475 & $<10$ & $\begin{array}{l}\text { No } \\
\text { Multicolinearity }\end{array}$ \\
\hline KI & .750 & $>0.1$ & 1,333 & $<10$ & $\begin{array}{l}\text { No } \\
\text { Multicolinearity }\end{array}$ \\
\hline
\end{tabular}

Source: results of data processing SPSS 22

of 0.10 and VIF is less than 10 , so we can conclude all independent variables multicollinearity.

\section{Autocorrelation Test}

Table 4: Test results autocorrelation

Based on Table 4 it can be seen

\begin{tabular}{lccl}
\hline & $\begin{array}{c}\text { Test } \\
\text { Run }\end{array}$ & Std & Information \\
\hline $\begin{array}{l}\text { Asymp.S } \\
\text { ig. (2- }\end{array}$ & .189 & $>0.05$ & $\begin{array}{l}\text { Non } \\
\text { autocorrelation }\end{array}$ \\
\hline tailed) & & & \\
\hline Source: results of data processing SPSS 22
\end{tabular}
that the value of the test run 0.189 more than 0.05 so that it can be concluded that the residual random (random) or free of autocorrelation

Source: results of data processing SPSS 22

\section{Heteroscedasticity Test}

\begin{tabular}{|c|c|c|c|c|c|c|}
\hline \multirow{3}{*}{\multicolumn{4}{|c|}{ Horoscedasticity }} & & & \\
\hline & & & & .920 & $>0.05$ & Non heteroskedastisitas \\
\hline & & & & 0.661 & $>0.05$ & Non heteroskedastisitas \\
\hline Model & Sig. & Std & Information & 0.403 & $>0.05$ & Non heteroskedastisitas \\
\hline SIZE & 0.679 & $>0.05$ & Non heteroskedastisit $I C R$ & .738 & $>0.05$ & Non heteroskedastisitas \\
\hline KA & 0.797 & $>0.05$ & Non heteroskedastisitas & Based & the : & ve table that \\
\hline KI & 0,900 & $>0.05$ & \multicolumn{4}{|c|}{ Non heteroskedastisitas sig on the independent variable is } \\
\hline \multicolumn{4}{|c|}{ Source: results of data processing SPSS 22} & \multicolumn{3}{|c|}{$\begin{array}{l}\text { more than } 0.05 \text {. So it can be } \\
\text { concluded that in this study are free } \\
\text { of heteroskesdastitas }\end{array}$} \\
\hline
\end{tabular}

\subsection{Regression analysis}

Table 6

* Corresponding author's e-mail: titiswidyayanti2716@gmail.com

http://openjournal.unpam.ac.id/index.php/EAJ 
EAJ (Economics and Accounting Journal) - Vol. 3, No. 1, Jan 2020 - Yanti, Hendra \& Chomsatu

Test Results Multiple Linear Regression

\begin{tabular}{cc}
\hline \multirow{2}{*}{ variables } & $\begin{array}{c}\text { Coefficients } \\
\text { unstandardized }\end{array}$ \\
\cline { 2 - 2 } & $\mathrm{B}$ \\
\hline (Constant) & -0.51 \\
SIZE & 0,002 \\
DER & 0,000 \\
ROA & -0.052 \\
CIR & -0.002 \\
ICR & 0,016 \\
KA & 0.007 \\
\hline KI & -0.027 \\
\hline
\end{tabular}

Source: results of data processing SPSS 22

The regression equation :

$$
\begin{aligned}
Y= & -0.51+0.002 \times 1 \times 2+0.000 \\
& +0.016-0.052 \times 3 \times 4 \times 5-0.002 \\
& -0.027+0.007 \text { X6 X7 }
\end{aligned}
$$

This means:

1. Without increasing the size of the company, leverage, profitability, capital intensity ratio, capital ratio inventory, audit quality, the value of the independent commissioner

effective tax rate will decrease by $-0.51$

2. The size of the company rose 1 point will increase effective tax rate amounted to 0,002

3. Leverage rose 1 point will increase effective tax rate amounted to 0,000 times.

4. Profitability rose 1 point will decrease effective tax rate amounted to -0.052 times

5. Capital intensity ratio rose 1 point will decrease effective tax rate amounted to -0.002 times.

6. Inventory capital ratio rose 1 point will increase effective tax rate amounted to 0.016 times

7. Quality audits rose 1 point will increase effective tax rate amounted to 0.007 times

8. Independent commissioner rose 1 point will decrease effective tax rate amounted to -0.027 times.

\section{Test The Feasibility Of The Model (Test F)}

Table 7

F Test Results

\begin{tabular}{llcccc}
\hline Ket & Fhit & Ftabel & Sighit & Sig. & result \\
\hline F Test & 4,455 & $>2.16$ & 0,000 & $<0.05$ & $\begin{array}{l}\text { Eligible } \\
\text { models }\end{array}$ \\
\hline
\end{tabular}

Source: results of data processing SPSS 22

\section{Hypothesis Test ( $T$ Test)}

Table 8

T Test Results

\begin{tabular}{llllll}
\hline Hypo & $\mathrm{t}$ & Ttabel & Sig. & Std & Information \\
\hline SIZE & 1.838 & 1,998 & 0.07 & 0.05 & Rejected \\
\hline DER & -0.191 & -1.998 & 0.84 & 0.05 & Rejected \\
\hline ROA & -2.226 & -1.998 & 0.03 & 0.05 & Accepted \\
\hline$C I R$ & -0.261 & -1.998 & 0.79 & 0.05 & Rejected \\
\hline$I C R$ & 2.652 & 1,998 & 0.01 & 0.05 & Accepted \\
\hline KA & 2,451 & 1,998 & 0.01 & 0.05 & Accepted \\
\hline KI & -2.015 & -1.998 & 0.04 & 0.05 & Accepted
\end{tabular}

Source: results of data processing SPSS 22

* Corresponding author's e-mail: titiswidyayanti2716@gmail.com 
EAJ (Economics and Accounting Journal) - Vol. 3, No. 1, Jan 2020 - Yanti, Hendra \& Chomsatu

\section{Discussion}

\section{The Effect Of Company Size To} Effective Tax Rate

Company size does not affect the effective tax rate. This means that the lower or the higher the size of a company does not affect the effective tax rate, the research results are in line with research Rahmawati and Mildawati (2019) which states that the size of the company does not affect the effective tax rate. Companies that have a large size with assets that can be managed to generate profits. But the company can ot take advantage of their assets to increase its profit.

\section{The Effect Of Leverage To Effective Tax Rate}

Leverage does not affect the effective tax rate. This means that the higher or even lower leverage does not affect the effective tax rate. Only leverage level will only affect the funding of the company instead of how companies generate profits. This is in line with research Ambarukmi and Diana (2017).

\section{The effect of Profitability to}

\section{Effective Tax Rate}

Profitability affect the effective tax rate. This means that the higher the profitability of the resulting lower effective tax rate value and vice versa companies with low profitability, the value higher effective tax rate. Companies that have a large profit will be in focus for the government so that the company will easily get lobbying to the government so that the tax burden is reduced.This study is in line with research conducted by Putri and Gunawan (2017),

\section{The Effect Of Capital Intensity} Ratio To Effective Tax Rate

Capital intensity ratio does not affect the effective tax rate. This means that the higher or lower capital intensity ratio does not affect the effective tax rate of a company. This study is in line with research conducted by Batmomolin (2018). Assets have an important role for the company's operations in order to gain profit.

\section{The effect of Inventory capital ratio to Effective Tax Rate}

Inventory capital ratio affect the effective tax rate. This means that the higher the value of inventory capital ratio higher the value of the effective tax rate. vice versa the lower the value of inventory capital ratio the lower the value of the effective tax rate. The company will invest a fortune on supplies. This makes the value of the effective tax rate will also increase. This study is in line with research conducted by Ambarukmi and Diana (2017).

\section{The Effect Of Quality Audits To Effective Tax Rate}

Quality audits affect the effective tax rate. This means that the higher the quality audit, the higher the effective value tac rate. vice versa the lower the lower the quality audit effective tax rate value. Quality audits can be seen from public accounting firms that audit. Public 
EAJ (Economics and Accounting Journal) - Vol. 3, No. 1, Jan 2020 - Yanti, Hendra \& Chomsatu

accounting firms are required to their transparency and accurate disclosure of truth. Companies audited by the big four accounting firm is more trusted than non-big four accounting firm. KAP big four would reduce tax avoidance measures. This study is in line with research conducted by Salaudeen and Akano (2018) states that affect the quality audit effective tax rate

\section{The Effect Of Independent Commissioner To Effective Tax Rate}

Independent commissioner affects the effective tax rate. This means that any increase or decrease in independent board affect the effective tax rate. Commissioners are one form of good governance in a The coefficient of determination company that is responsible for controlling and monitoring the company's management in making decisions for the company. The Board of Commissioners also oversees the company's management to comply with and implement the law taxation applicable in Indonesia. This study is in line with research conducted by Wulansari et al (2015) which prove that the commissioners affect the effective tax rate. This study contradicts the studies conducted by Marita et al (2013) which states that the independent board does not affect the tax effective rate.

Table 9

Coefficient Determination Test Results

\begin{tabular}{ccl}
\hline Model & Adjusted R Square & \multicolumn{1}{c}{ Information } \\
\hline 1 & 0.273 & variable firm size, leverage, profitability, capital intensity \\
& ratio, inventory capital ratio, quality audits, independent \\
& commissioner simultaneously affect the variable effective \\
& tax rate 27,3\% \\
\hline
\end{tabular}

Source: results of data processing SPSS 22

\section{CONCLUSION}

Based on research that has been done, it can be concluded that:

1. Variable size of the company does not affect the effective tax rate. This research is in line with research Rahmawati and Mildawati (2019).

2. Variable leverage does not affect the effective tax rate. This study is in line with research Batmomolin (2018).
3. Profitability variables affect the effective tax rate. The study was consistent with research daughter and Gunawan (2017).

4. Variable capital intensity ratio does not affect the effective tax rate. This study is in line with research Batmomolin (2018).

5. Capital intensity ratio variables affect the effective tax rate. This study is in line with research Pertiwi et al (2018).

6 . Variables affect the quality audit of the effective tax rate. This

* Corresponding author's e-mail: titiswidyayanti2716@gmail.com

http://openjournal.unpam.ac.id/index.php/EAJ 
EAJ (Economics and Accounting Journal) - Vol. 3, No. 1, Jan 2020 - Yanti, Hendra \& Chomsatu

study is in line with research Salaudeen and Akano (2018).

7. Independent commissioner variables affect the effective tax rate. This research is in line with research from Wulansari et al (2015).

\section{REFERENCE}

Ambarukmi, KT, \& Diana, N. (2017). Effect of Size, Leverage, Profitability, Capital Intensity Ratio And Activity Of Effective Tax Rate (ETR) (Empirical Study On LQ-45 Company Listed on the Stock Exchange During the Period 20112015). Scientific e-Jurnal Accounting Research, 6(17).

Batmomolin, S. (2018). Leverage Analysis, Firm Size, Intensity Fixed Assets Inventory And Intensity Of Effective Tax Rate (In Chemical Company Listed on the Indonesia Stock Exchange Year 2012 to 2017). Scientific journals Economic Bulletin.

Damayanti, T., \& Gazali, M. (2018). Effect of Capital Intensity Intensity Ratio And Inventory Of Effective Tax Rate. Scholars 4th National Seminar.

Gurawati, D. (2013). Basic Economeric 4th edition. New York: Mc GrawHill Companies.

Kurniasari, E., \& Listiawati. (2019). Leveragedalam Affects Profitability And Effective Tax Rate. Management Journal, 9(1)

Pertiwi, K., Manik, T., \& Husna, A. (2018). Effect of Intensity of Capital, Leverage, Intensity Supplies, Affiliated Company Transaction, Transfer Pricing and Tax Effective Against Rates On
Manufacturing Company Listed on the Indonesia Stock Exchange Year 2013 to 2016.

Prihaningtyas, et all (2018). Effect of Profit, Total Assets, and Total Debt to Effective Tax Rate On Infrastructure Company in Indonesia. LMU Journal of Economics, 145 - 155.

Daughter, AN, \& Gunawan. (2017). Effect of Size, Profitability and Liquidity of the Effective Tax Rates (ETR) Foreign Exchange Banks Period 2010 - 2014, Journal of Banking and Finance, 14(1), 18-28.

Rahmawati, V., \& Mildawati, T. (2019). Effect of Size, Leverage, Profitability, Dancapital Intensity Ratio Of Effective Tax Rate (ETR). JRKA, 5(2), 81-105.

Richardson, G., \& Lanis, R. (2007). Determinants Of the Variability in Corporate Effective Tax Rate and Tax Reform: Evidence from Australia. Journal of Accounting and Public Policy, 6, 689-704.

Salaudeen, PhD, YM (2017). Effective Corporate Tax Rates in the Financial Services Sector: Evidence from Nigeria. International Journal of Accounting and Taxation, 5(1), 68-88.

Salaudeen, YM, and Akano, RO (2018). Non-Linearity in the Determinants of Corporate Effective Tax Rate: Further Evidence from Nigeria. 
EAJ (Economics and Accounting Journal) - Vol. 3, No. 1, Jan 2020 - Yanti, Hendra \& Chomsatu

International Journal of Economics and Financial Research, 56-63.

Sarjono, H., \& Julianita. (2013). SPSS vs LISREL A Pengantar Aplikasi To Research. Jakarta: Four Salemba.

Setiawanx, A., \& Al-Ahsan, MK (2016). Effect of Size, Leverage, Profitability, Audit Committee, Independent Commissioner Dan Against the Investor Constitutional Effective Tax Rate (ETR). CIDA EKA Journal, 1(2).

Sugiono. (2016). Business Research Methods. Bandung: Alfabeta.
Sukrisno, A., \& Trisnawati, E. (2013). Tax accounting. Jakarta: Four Salemba.

Wijaya, se, and Febrianti, m. (2017). Effect of Size, Leverage, Profitability, Inventory and Govermence Against Corporate Tax Management. Journal of Business and Accounting, 274-280.

Wulansari, et all (2015). Influence of Corporate Governance Characteristics Of Effective Tax Rate (ETR) (Empirical Study On Banking Companies Listed On Bei Years 2011-2013). Jom FEKON, 2(2). 